\title{
The role of the Wnt signaling pathway in osteoblast commitment and differentiation
}

\author{
Maria P. Yavropoulou, ${ }^{1}$ John G. Yovos ${ }^{2}$ \\ ${ }^{1}$ Research Fellow in Endocrinology and Metabolism, ${ }^{2}$ Professor of Endocrinology and Metabolism, Aristotle University \\ of Thessaloniki, AHEPA University Hospital, Thessaloniki, Greece
}

\begin{abstract}
Wnts are a large family of proteins that participate in an array of cellular biological processes such as embryogenesis, organogenesis and tumor formation. These proteins bind to membrane receptor complexes comprised of a frizzled (Fz) G-protein-coupled receptor and other membrane co-receptors forming molecular groups that initiate, at least, three different intracellular signaling cascades leading to nuclear generation of transcription factors which regulate various cellular events. These events result in selective cellular differentiation, reduction or inhibition of the apoptotic mechanisms or changes in the biologic behavior of various cell lines. During the last decade, canonical Wnt signaling has been shown to play a significant role in the control of osteoblastogenesis and bone formation. In several clinical cases, mutations have been found in the Wnt receptor complexes that are associated with changes in bone mineral density and fractures. Loss-of-function mutations in LRP5 receptors cause, osteoporosis-pseudoglioma syndrome, while gain-of-function mutations in the same group lead to high bone mass phenotypes. Furthermore, osteocytes secrete proteins such as sclerostin, which blocks the membrane complex activation by Wnt, resulting in inhibition of bone formation. Studies of knockout and transgenic mouse models for Wnt pathway components have demonstrated that canonical signaling regulates most aspects of osteoblast physiology including commitment, differentiation, bone matrix formation/mineralization and apoptosis as well as coupling to osteoclastogenesis and bone resorption. Future studies in this rapidly growing area of research can possibly lead to the identification of targets of pharmacological intervention useful in the management of osteoporosis. In the present review we summarized the current knowledge related to the various components of the Wnt signaling pathway, the ways they cooperate in inducing and directing transcriptional functions as well as the interacting points with the TGFß superfamily. We also outlined a probable working integrating model of the mechanism of bone formation.
\end{abstract}

Key words: BMPs, Glitazones, Osteoblastogenesis, Osteoblasts, Osteoclasts, PPAR- $\gamma$, Smads, $\mathrm{TGFb}, \mathrm{Wnt}$ signaling 


\section{INTRODUCTION}

The realization that osteoporosis constitutes a significant global health problem has been followed by an intense effort in the clinical as well as in the research field. Today, the prevention and treatment of osteoporosis mainly involves the use of antiresorptive agents that target osteoclast function. Nonetheless, antiresorptive therapies are associated with moderate increases in BMD and only moderate reduction in the risk of fractures. For that reason, the search for anabolic agents, which target osteoblast function, is imperative. The approved bone anabolic drugs for the treatment of osteoporosis are teriparatide (human parathyroid hormone 134) and recombinant human PTH 1-84. Recently, both human genetic and animal studies have pointed to the role of the Wnt/LRP5 pathway as a major regulator of bone mass formation. Wnts are a family of 19 secreted glycoproteins that bind to receptor complexes including low-density lipoprotein receptor-related protein (LRP)-5/6 as well as frizzled proteins. A subsequent intracellular cascade of events stabilizes $\beta$-catenin, leading to its translocation into the nucleus where, associated with Tcf/Lef transcription factors, it triggers gene expression. The existence of potential pharmacological targets in this pathway makes it attractive for bone anabolic drug discovery. In this review we summarize the current knowledge related to the elements and the known functions of the Wnt signaling system and give an overall outline of the integration of this system in the bone morphogenetic procedures.

For the purpose of clarity, the review begins with a description of the components of the Wnt pathway. Some aspects of the properties and functions of the TGF (Transforming Growth Factor) super-family have been added to provide a more integrative view of the signaling. In the final part a working model of the entire system is outlined.

\section{THE WNT FAMILY OF PROTEINS}

Wnt form a family of 19 highly conserved secreted signaling molecules, rich in cystein, which plays an important role in osteoblastogenesis and bone formation. ${ }^{1,2}$ The name derives from the first 2 members of the family: int- 1 (mouse) and wingless (Drosophila). ${ }^{3}$ The number of Wnts involved in osteoblastogenesis has yet to be delineated. It is likely that Wnt activity in bone marrow is exerted through various stages of development and important contributions from several Wnts have been described. The Wnt1 (Wnt1, Wnt3a) class activates the canonical Wnt signaling pathway, which involves the formation of a complex between Wnt proteins, frizzled and LRP5 or LRP6 receptors. ${ }^{4,5}$ These complexes promote the phosphorylation and inactivation of GSK3b, the inhibition of $\beta$-catenin degradation and the subsequent accumulation of $\beta$ catenin in the nucleus. ${ }^{6,7}$ The non-canonical Wnt5a class binds to frizzled proteins, activates heterotrimeric $G$ proteins and increases intracellular calcium via protein kinase $\mathrm{C}$-dependent mechanisms or induces Rho- or c-Jun N-terminal kinase (JNK)-dependent changes mediating the formation of cytoskeleton. ${ }^{8}$ The Wnt proteins are secreted from cells in a very hydrophobic form that can only be solubilized in detergent. ${ }^{9,10}$ This insolubility is due to a covalent attachment of palmitate to a conserved cysteine near the amino terminus of the Wnt protein. ${ }^{11,12}$ Enzymatic removal of palmitate results in loss of activity. Findings of mutational analysis of the modified cysteine indicate that the palmitoylation is important for Wnt signaling. ${ }^{11,12}$ In addition to lipidation, Wnts are also modified by glycosylation, but this modification is not essential for activity ${ }^{13}$ (Table 1).

\section{CELL MEMBRANE RECEPTORS}

\section{3a. LRP5/6 receptor family}

There are currently at least 13 known members of the LDL receptor family that serve a variety of transport and cell signaling functions in various tissues and cell types. ${ }^{16}$ All members of the family are single-pass transmembrane proteins that contain highly conserved motifs; most notably, all contain copies of a complement-like, cysteine-rich repeat motif (the LDL repeat). In addition, most contain a tyrosine-tryptophan-threonine-aspartate (YWTD) amino acid repeat that forms a propeller structure critical for proper function (ligand binding). Another common feature of most members is the presence of an epidermal growth factor (EGF)-like repeats motif and an NPxY sequence in the cytoplasmic tail that serves as a signal sequence for endocytosis of the receptor. ${ }^{17}$ Human low-density lipoprotein (LDL) receptor-related proteins 5 (LRP5) and 6 are homologous 
Table 1. The Wnt family of proteins. Gene loci and associated diseases.

\begin{tabular}{|c|c|c|}
\hline WNT proteins & Gene Locus & Associated diseases \\
\hline WNT1 & $12 q 13$ & \\
\hline WNT2 & $7 q 31$ & \\
\hline WNT2B & $1 \mathrm{p} 13$ & \\
\hline WNT3 & $17 q 21-q 21$ & Tetra-Amelia ${ }^{12}$ \\
\hline WNT3A & $1 q 42$ & \\
\hline WNT4 & 1p36.23-p35.1 & $\begin{array}{l}\text { Mullerian-duct regression and } \\
\text { virilization }^{13}\end{array}$ \\
\hline WNT5A & $3 \mathrm{p} 21-\mathrm{p} 24$ & \\
\hline WNT5B & $12 \mathrm{p} 13.3$ & $\begin{array}{l}\text { Susceptibility to type } 2 \text { diabe- } \\
\text { tes }^{14}\end{array}$ \\
\hline WNT6 & $2 q 35$ & \\
\hline WNT7A & $3 p 25$ & \\
\hline WNT7B & $22 q 13$ & \\
\hline WNT8A & $5 q 31$ & \\
\hline WNT8B & $10 q 24$ & \\
\hline WNT9A & $1 q 42$ & \\
\hline WNT9B & $17 \mathrm{q} 21$ & \\
\hline WNT10A & $2 q 35$ & \\
\hline WNT10B & $12 q 13$ & Obesity $^{15}$ \\
\hline WNT11 & $11 q 13.5$ & \\
\hline WNT16 & $7 q 31$ & \\
\hline
\end{tabular}

Source: http://genome-www.stanford.edu/cgi-bin/genecards/

to the Drosophila protein Arrow. ${ }^{18}$ They are unique with respect to other members of the LDL receptor family in that they do not contain the internalization signal sequence for endocytosis. The LRP5 protein contains 1615 amino acids, whereas LRP6 contains 1613 amino acids. Overall, homology between LRP5 and 6 at the nucleotide level is $64 \%$, whereas coding sequence homology is $71 \% .{ }^{19}$ Given the importance of the LDL receptor family for the uptake of lipids and other macromolecules, and considering that Wnts are lipid-modified and dependent on the lipid for signaling activity, it is tempting to speculate that LRPs specifically interact with the lipid on the Wnt and thereby promote signaling. While this is an attractive possibility, there is yet no evidence supporting it, and it is also likely that the interaction is indirect involving an apoprotein that is bound to the lipid on the Wnt molecule. Further research is necessary to unravel the mechanisms involved. The extra-cellular portion of LRP5/6 binds several different molecules, principally the Wnts and Dkks, and the co-receptor protein, frizzled. LRP5/6 functions cooperatively with
Fz to stimulate the catenin pathway in response to different Wnt proteins. ${ }^{20}$

\section{3b. Frizzled Receptor Family}

Frizzled proteins are seven-transmembrane serpentine receptors, which consist of an extra-cellular cysteine-rich domain (CRD) that serves as a ligand-binding unit and a 7-transmembrane signaling portion. ${ }^{21-24}$ The extra-cellular CRD at the amino terminus of frizzled proteins binds Wnt proteins, as do homologous domains in soluble proteins - termed secreted frizzled-related proteins - that function as antagonists of Wnt signaling. LRP5/6, the co-receptor for Wnt proteins, also binds to a frizzled CRD in a Wnt-dependent manner. Ten members of the frizzled receptors family have been described but little is known about the mechanism of frizzled signaling. Some but not all frizzled proteins stimulate $\mathrm{Ca}^{2+}$ release and PKC activity. ${ }^{25}$

\section{INHIBITORS OF WNT SIGNALING (Table 2)}

\section{4a. Dkk/Kremen}

Dickkopfs (Dkks) are secreted developmental regulators composed of two cysteine-rich domains that induce head formation in amphibian embryos. ${ }^{26}$ There are 4 Dkk members (DKK1-4) in the human genome. Dkk interferes with Wnt signaling by binding directly to LRP5/6. ${ }^{27,28}$ At the same time Dkk interacts with Kremen, another transmembrane protein. ${ }^{29} \mathrm{Kre}-$ men-1 and Kremen-2 are transmembrane proteins, which form Dkk receptors, which bind to both Dkk1 and Dkk2 with high affinity. ${ }^{30}$ Kremen- 2 forms a tertiary complex with Dkk1 and LRP6. This complex is internalized, removing LRP from the cell surface and making LRP unavailable for Wnt signaling. ${ }^{30}$ Thus Dkk1 blocks Wnt/ $\beta$-catenin signaling induced osteoblastogenesis. However, during terminal osteoblast differentiation Wnt//-catenin signaling - presumably initiated by $\mathrm{Wnt} 7 \mathrm{~b}$-induces expression of Dkk2, which is then surprisingly required for subsequent mineralization. ${ }^{31}$ Dkk2-/- mice have increased se-

Table 2. Inhibitors of Wnt signaling.

\begin{tabular}{lc}
\hline Bind to Frizzled receptor & Bind to LRP5/6 receptor \\
\hline sFrp & Dkk/Kremen \\
Wif & Sclerostin/Wise \\
\hline
\end{tabular}


creted matrix (osteoid) but impaired mineralization, leading to an osteopenic phenotype. Because expression of another Wnt antagonist, sFRP3, differs from Dkk2 expression in restoring Dkk2 deficiency and regulating osteoblast differentiation, the effects of Dkk2 on terminal osteoblast differentiation may not be entirely mediated by its Wnt signaling antagonistic activity. ${ }^{31}$

\section{4b.Sclerostin/Wise}

Sclerostin is the protein product of the Sost (sclerosteosis) gene located on chromosome 17q12-q21, the loss of which causes sclerosteosis and van Buchem disease, ${ }^{32,33}$ two rare, closely related skeletal disorders characterized by a substantial increase in bone mass. The expression of sclerostin in the adult is highly restricted to osteocytes and shows a similar time course to that of osteocalcin. Sclerostin only occurs at late stages of differentiation, presumably when osteocytes are buried in bone matrix. It is proposed that sclerostin may serve as an integral connection for the osteocytic-mediated regulation of bone remodeling, controlling the proliferation and differentiation of osteoprogenitor/pre-osteoblastic cells as well as the activity of mature osteoblasts by down-regulating BMP activity. ${ }^{34}$ Based on its amino acid sequence, sclerostin is a member of the Dan family of glycoproteins, many members of which have been reported to antagonize BMP activity. ${ }^{33,35}$ Sclerostin inhibits BMP-stimulated bone formation but does not affect BMP signaling and phosphorylation of Smads and thus its mechanism of action seems to be different from classical BMP antagonists. ${ }^{35,36}$ Instead, it inhibits Wnt signaling. Sost and its homolog Wise belong to the cysteine knot protein subfamily and modulate the Wnt pathway by binding to LRP5 and LRP6. ${ }^{37-39}$ In particular, Sost identifies the first two YWTD-EGF repeat domains of LRP5 as being responsible for the binding. Although these two repeat domains are required for transduction of canonical Wnt signals, canonical Wnt did not appear to compete with sclerostin for binding to LRP5. ${ }^{40} \mathrm{Wise}$ shares $38 \%$ amino acid identity with sclerostin and appears to be a context-dependent regulator of Wnt signaling; it may inhibit or stimulate Wnt signaling. ${ }^{40}$ Wise can also bind to LRP6 and compete with Wnt8 for binding to LRP6. ${ }^{41}$

\section{4c. sFRP}

Secreted frizzled-related proteins (sFRPs) are expressed by osteoblasts. They contain a cysteine-rich domain (CRD) that is highly homologous to the CRD in the frizzled receptors, but lack the transmembrane domain and are secreted as extra-cellular proteins. They are approximately $30 \mathrm{kDa}$ in size and each contains a putative signal sequence, a frizzled-like cysteine-rich domain and a conserved hydrophilic carboxy-terminal domain. ${ }^{42}$ They are capable of binding Wnt and preventing it from binding to the LRP5/6 -frizzled receptor. sFRP has also been shown to bind to RANKL and prevent its interaction with RANK, which raises the possibility that, analogous to the binding of RANKL by (OPG), sFRP-1 may regulate osteoclastogenesis. ${ }^{43}$

\section{4d. Wif}

Wnt inhibitory factor-1 (WIF-1) is a secreted protein that binds to Wnt proteins and inhibits their activities. WIF-1 proteins comprise an N-terminal signal sequence, a family-specific WIF domain, five epidermal growth factor (EGF) repeats and a hydrophilic C-terminus. The interaction of Wnt proteins with WIF-1 is similar to other secreted inhibitors, such as frizzled-related protein. ${ }^{46}$

\section{CYTOSOLIC COMPOUNDS}

\section{5a. Disheveled (Dvl)}

Disheveled is one of the multi-module proteins operating in the Wnt pathway. The Dvl family of proteins (Dvl-1, -2 and 3 in mammalian, Dsh in Drosophila) have no known enzymatic functions but they possess several potential interaction motifs, namely an N-terminal DIX (Disheveled-Axin) domain, a central PDZ (Post-synaptic density 95, Discs Large, Zonula occludens-1) domain and a C-terminal DEP (Disheveled-EGL-10-Pleckstrin) domain. ${ }^{47-51}$ The DEP domain can be found in signaling factors, such as the RGS (regulzator of G-protein signaling) protein family, that are involved in $G$ protein signaling. It is not yet known whether DEP domains play an active role in regulating $\mathrm{G}$ protein, but they are necessary and sufficient to translocate the Dvl protein to the membrane when frizzled proteins are expressed ${ }^{52}$ and are also required for planar polarity signaling. Dvl receive signals from the $\mathrm{Fz} / \mathrm{LRP}$ complex, leading to inhibition of GSK3b. The protein has been found at multiple locations in cells, including the nucleus. ${ }^{53}$ The 
$\mathrm{N}$-terminal DIX domain is similar to the Axin DIX domain. There is a direct interaction between Axin and Dvl-2, resulting in the transmission of the Wnt signal from Dvl-2 to GSK3b. ${ }^{54}$ It is possible that the interaction of Dvl-2 with Axin between residues 602 and 810 brings the DIX domain of Dvl-2 into close contact with that of Axin, promoting or disrupting their interaction. Alternatively, the DIX domain of Dvl-2 may simply serve to localize the protein to the same compartment as Axin, facilitating their interaction via other domains. Moreover, Dvl also interacts with FRAT-1, which is the mammalian homolog of GSK3b binding protein (GBP). GBP can then interact with and inhibit GSK3b, which results in activation of the Wnt pathway. ${ }^{54}$

\section{5b. Axin (Figure 1)}

Axin is a central component of the canonical Wnt signaling pathway. It serves as a scaffolding protein, which assembles a multi-protein complex with APC (Adenomatous polyposis coli), GSK3b (Glycogen Synthase Kinase 3) and CKIa (Casein Kinase Ia). This complex is devoted to $\beta$-catenin phosphorylation and degradation. ${ }^{55}$ When Wnt proteins bind to frizzled and LRP-5, Axin is recruited to the membranes. The interaction between Axin and the intracellular domain of LRP-5 prevent Axin from participating in the degradation of $\beta$-catenin, at least in part by destabilizing Axin. ${ }^{56}$ In addition, the LRP-5 sequences

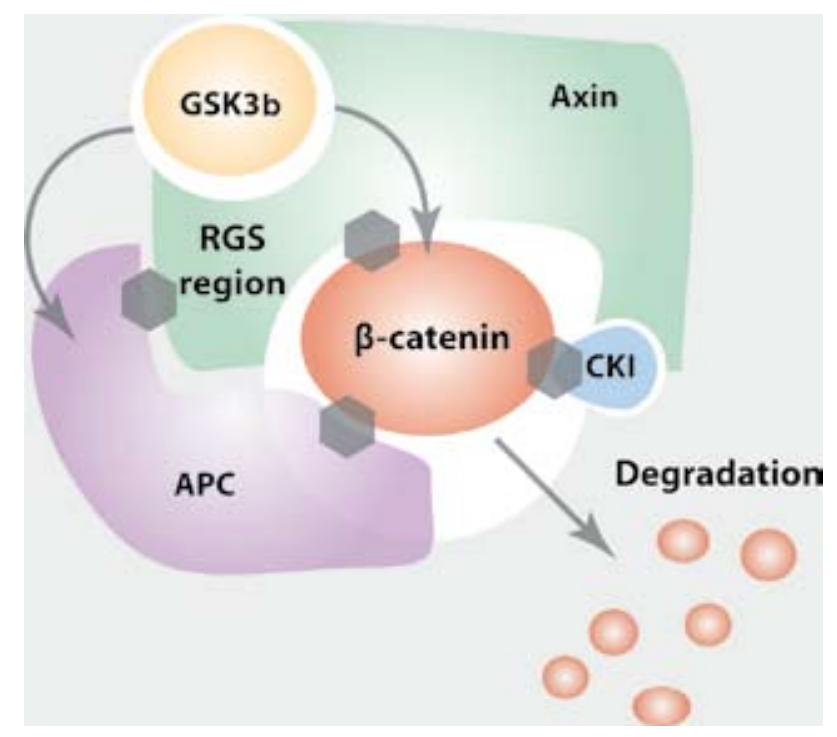

Figure 1. The Axin, APC, $\beta$-catenin complex. involved in interactions with Axin are required for LEF-1 (transcription factor) activation. ${ }^{56}$ Several domains on the Axin protein have been mapped. The RGS (Regulators of G protein signaling) domain in the N-terminal region interacts with APC..$^{57,58}$ The DIX domain in the C-terminal region is similar to a domain in disheveled, as mentioned above, and promotes interactions between these two domains. Axin also binds to the phosphatase PP2A. Separate binding domains for $\beta$-catenin, GSK3b and CKIa have been found. There are two vertebrate Axin genes, which act as negative regulators. Axin1 is constitutively expressed, but Axin2 (also called Conductin, or Axil) is induced by active Wnt signaling and acts therefore in a negative feedback loop. ${ }^{59,60}$ Axin and Axin2 are functionally equivalent in vivo. ${ }^{61}$ Germ line mutations in the human Axin2 gene cause familial tooth agenesis and predispose to colorectal cancer. ${ }^{62}$

\section{5c. $A P C$}

APC (Adenomatous Polyposis coli) is a large protein that has multiple roles in the cell. ${ }^{63} \mathrm{In}$ the Wnt pathway, APC binds to the $\beta$-catenin complex and is necessary for its down-regulation. APC interacts directly with Axin. There are two human and two Drosophila APCs. Human APC1 is a major tumor suppressor gene in colon cancer. Combined activity of APC1 and APC2 allows a tight regulation of transcriptional activation by $\beta$-catenin and suggest that APC proteins are required for the regulation of Wnt transduction in all cells. ${ }^{64}$ The overlapping functions exist despite striking differences in the intracellular localization of the two APC family members.

\section{5d. GSK3b}

Glycogen synthase kinase $3 \mathrm{~b}$ is a serine/threonine kinase involved in insulin, growth factor and Wnt signaling. In Wnt signaling, GSK3b is recruited to a multi-protein complex via interaction with Axin, where it phosphorylates three serine (S)/threonine $(\mathrm{T})$ residues $(\mathrm{S} 33, \mathrm{~S} 37, \mathrm{~T} 41$,$) at the amino-terminal$ region of $\beta$-catenin. ${ }^{65}$ These phosphorylated $\mathrm{S} / \mathrm{T}$ residues are critical for its recognition by the $\mathrm{F}$ box protein $\beta$-Trcp, which is the specificity component of an ubiquitination apparatus. Wnt-signal transduction through $\beta$-catenin is thought to require the inhibition of GSK3b by Frat/GBP, which is recruited to the Dvl, Axin and GSK3b complex, probably by Dvl, when 
the latter binds to Fz/LRP5-6 receptor. Formation of this quaternary complex may be an important step in Wnt signaling, leading to GBP-mediated dissociation of GSK3b from Axin and consequent accumulation of $\beta$-catenin. ${ }^{66}$ However, Frat is not proved to be an essential component of the canonical Wnt pathway in higher organisms. Axin also provides a binding site for the $\alpha$-isoform of casein kinase I (CKI $\alpha)$, which phosphorylates $\beta$-catenin on Ser45 and 'primes' the sequential phosphorylation of Thr41, Ser37 and Ser33 by GSK3b. In vitro, GSK3b can phosphorylate other components of the Wnt pathway, including Axin, Apc and Tcf-2. GSK3b phosphorylation of Axin and Apc enhances their ability to bind to $\beta$-catenin and stabilizes Axin protein, all contributing to $\beta$-catenin degradation. Whether this phosphorylation requires priming phosphorylation by CKIa or other kinases is not known. ${ }^{67}$ Insulin and Wnt inhibit GSK3b phosphorylation of GS (glycogen synthase) and $\beta$-catenin, respectively. This specificity appears to depend, at least in part, on whether GSK3b is inhibited via phosphorylation by Akt upon insulin signaling. ${ }^{68-70}$ or via disheveled and GBP binding to GSK3b and Axin upon Wnt signaling. ${ }^{71-73}$

\section{5e. CKIa}

CKIa, a $37 \mathrm{kDa}$ protein, is a component of the Axin complex. CKIa and GSK3b bind to different regions of Axin in such a way that they "sandwich" $\beta$-catenin in the Axin complex, thereby promoting effective $\beta$-catenin phosphorylation. Wnt signaling inhibits GSK3b but not CKIa phosphorylation of $\beta$-catenin; therefore, CKIa may represent a node at which other signaling pathways regulate $\beta$-catenin protein. ${ }^{74}$

\section{5f. $\beta$-Catenin}

$\beta$-catenin (armadillo in Drosophila) is a cytoplasmic phosphoprotein under resting conditions and the key mediator of the Wnt pathway. Upon Wnt activation it cannot be phosphorylated by GSK3b, resulting in its cytoplasmic accumulation and translocation to the nucleus. ${ }^{75}$ In the nucleus $\beta$-catenin interacts with transcription factors and controls the transcriptional activation of the genes. Activating mutations in the human $\beta$-catenin gene have been found in human colon cancer and melanomas. ${ }^{76}$

\section{5g. PI3K-Akt signaling}

Akt is a serine-threonine kinase whose amino terminus contains a pleckstrin homology, and is activated by various extra-cellular stimuli, including insulin and IGF-1, through the phosphatidylinositol 3-kinase (PI3K) pathway. It is likely that Akt mediates cell migration at least partly by activating Rac and p21-activated protein kinase. In various cell culture systems, PI3K-Akt signaling has been implicated as a critical pathway for the differentiation of skeletal component cells including chondrocytes, osteoblasts, myoblasts and adipocytes. There is linkage of Runx2 and the PI3K-Akt signaling pathway in osteoblast and chondrocyte differentiation and their migration. ${ }^{77}$ However, PI3K-Akt signaling is involved in multiple cell functions including cell proliferation, apoptosis, cell growth and glucose metabolism in addition to cell differentiation and migration. Therefore, the cell phenotypes resulting from the coupling of Runx2 and PI3K-Akt signaling may be more complex. Furthermore, Wnt proteins, irrespective of their ability to stimulate canonical Wnt signaling, prolong the survival of osteoblasts and uncommitted osteoblast progenitors via activation of the Src/ERK and PI3K/ Akt signaling cascades. ${ }^{78}$

\section{NUCLEAR TRANSCRIPTION FACTORS}

\section{6a.Tcf/Lef}

The founding members of the TCF family are Tcell factor-1 (Tcf-1) and lymphoid enhancing factor-1 (Lef-1). These transcriptional factors are activated in response to Wnt signaling. ${ }^{79} \mathrm{TCF}$ provides sequencespecific binding activity and, in the absence of nuclear catenin, binds transcriptional co-repressors and forms a repressive complex that blocks transcription of Wnt target genes. ${ }^{80,81}$

\section{6b. Runx2/Cbfal}

The RUNX/CBFA/AML/PEBP family of transcription factors includes three distinct genes. Cbfa1 (Core binding factor a1)/Runx2 (runt related transcriptional factor 2) determines the osteoblast lineage from multi-potent mesenchymal cells, induces osteoblastic differentiation at the early stage and inhibits it at the late stage. ${ }^{82,83}$ Further, Runx2 has been shown to induce alkaline phosphatase (ALP) activity, expression 
of bone matrix protein genes and mineralization in immature mesenchymal cells and osteoblastic cells in vitro. ${ }^{84,85}$ There is a complete lack of intramembranous and endochondral bone formation in Cbfa1/Runx-2 null mice, ${ }^{86}$ and haploinsufficiency of this gene results in cleidocranial dysplasia (CCD), a dominantly inherited developmental disorder of bone ${ }^{87}$ Recent evidence demonstrates that Runx 2 forms a complex with Lef1 or TCF, and this complex binds a composite binding site in the FGF18 (fibroblast growth factor) promoter, inducing FGF18 expression, which is an essential regulator of bone development. In that way, two transcription pathways that are essential for bone physically and functionally converge at the FGF18 promoter. ${ }^{85}$

\section{WNT PATHWAYS}

All components described in Figure 2 operate in three different pathways. These pathways can interact with each other enhancing or diminishing their activity. The three distinct pathways are:

\section{a. The Wnt/ק-catenin or canonical pathway}

Absence of Wnt expression or inhibition of their binding to membrane receptors leads to degradation of $\beta$-catenin and inactivation of the signaling cascade. Axin assembles a multi-protein complex with APC, GSK3b and CKIa, permitting GSK3b and CKIa to bind and phosphorylate $\beta$-catenin, allowing its degradation by the $\beta$-Trcp mediated ubiquitin proteasome pathway ${ }^{86}$ In the nucleus, TCF/LEF transcription factors join with transcriptional co-repressor Groucho and histone deacetylases to form a repressive complex and block transcription of Wnt target genes..$^{87,88}$ Activation of Wnt/ $\beta$-catenin signaling is initiated by binding of Wnt to the 7-transmembrane domain-spanning frizzled

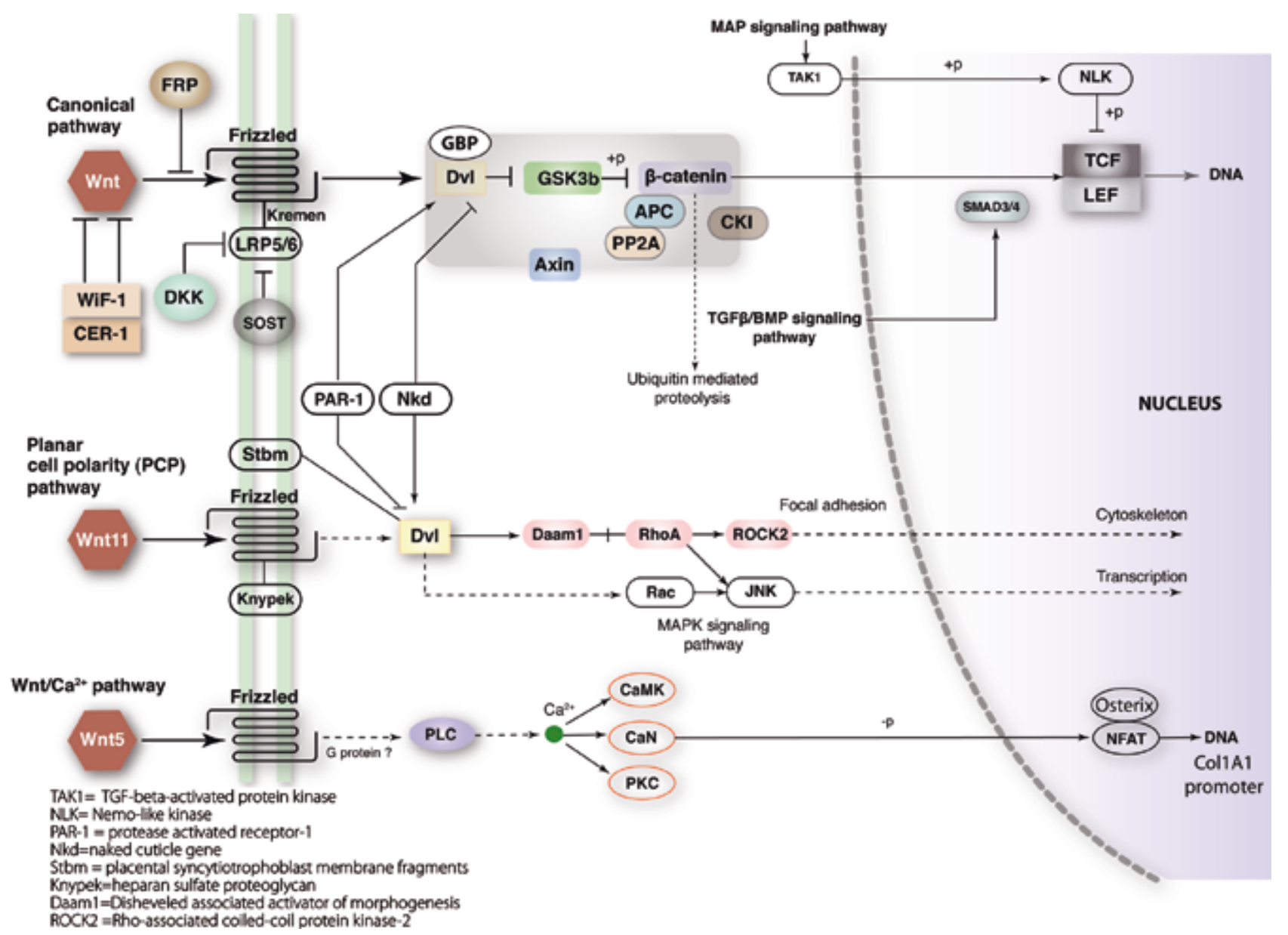

Figure 2. The canonical signaling: Wnt/ $\beta$-catenin pathway. The non-canonical signaling: $\mathrm{Wnt} / \mathrm{ca}^{2+}$ pathway. The non-canonical signaling: Planar cell polarity pathway. 
receptor and low-density lipoprotein receptor-related protein 5 and 6 (LRP5/6) co-receptors. Part of the cytoplasmic pool of disheveled is then phosphorylated and recruited to the membrane. Dvl, Axin and GSK3b form a ternary complex bridged by Axin, and Frat1/GBP is recruited into this complex, probably by Dvl, and competes with Axin in binding to GSK3b, resulting in the dissociation of GSK3b from Axin. $\beta$-catenin accumulates and enters the nucleus where it binds to TCF/LEF transcription factors. Binding of $\beta$-catenin displaces transcriptional co-repressors bound to TCF/LEF and recruits transcriptional coactivators, e.g. the histone acetylase p300/CBP and CREB (cAMP response element-binding protein), which act through the remodeling of chromatin surrounding TCF binding sites. ${ }^{89-91}$ The formation of the heterodimeric $\beta$-catenin-TCF/LEF is crucial for the activation of gene transcription from Runx 2 promoter, which contain TCF binding sites.

\section{b. The $\mathrm{Wnt} / \mathrm{Ca}^{2+}$ pathway}

Wnt5a, after binding to Rfz2, causes the cytosolic G-Protein to break off into its $\alpha$ and $\beta / \gamma$ components. The G $\alpha$ subunit activates phosphodiesterase (PDE), which inhibits cyclic guanosine monophosphate (cGMP) activity in the cell. The $\mathrm{G} \beta / \gamma$ subunits activate phospholipase C (PLC), which in turns hydrolyzes phosphatidylinositol 4,5-bisphosphate (PIP2) into inositol 1,4,5-trisphosphate (IP3) and diacylglycerol (DAG). DAG activates protein kinase C (PKC), while IP3 increases the $\mathrm{Ca} 2+$ level in the cell, activating calcineurin and $\mathrm{Ca}^{2+}$-calmodulin-dependent protein kinase II (CamKII). Finally, calcineurin activates the nuclear factor of activated T cells (NFAT), influencing gene expression.

\section{c. The planar polarity cell pathway}

In flies mutant for $\mathrm{fz}$, the normally uniform direction of hair and bristles on the wings and thorax are perturbed, a result of disrupting what is now known as the planar cell polarity (PCP) pathway. ${ }^{92}$ This signaling pathway includes frizzled and disheveled but not the Axin complex proteins. ${ }^{93}$ The non-classical cadherins (a class of transmembrane proteins that play important roles in cell adhesion and are dependent on calcium ions to function) can apparently modulate frizzled function. Other proteins, including rhoA and rho-kinase, act downstream of frizzled and disheveled to regulate the cytoskeleton and planar cell polarity. Disheveled acts in both the PCP pathway and the canonical Wnt signaling pathway. ${ }^{94}$ Analysis of Dvl mutations that disrupt PCP signaling but not Wnt signaling have demonstrated that there is a specific domain that acts in PCP signaling but not in canonical Wnt signaling. ${ }^{94}$

\section{THE TGF-B SUPER-FAMILY}

Transforming growth factor- $\beta$ (TGF- $\beta$ ) is a potent growth inhibitor for a wide variety of cells. Three isoforms of TGF- $\beta$, i.e. TGF- $\beta 1$, TGF- $\beta 2$, and TGF$\beta 3$, with similar structures and in vitro biological activities, have been identified in mammals. TGF- $\beta$ is produced by osteoblasts and is incorporated in the bone matrix. During the resorption phase of remodeling, TGF- $\beta$ is released in active form and plays an important part in the regulation of osteoblast proliferation, differentiation and apoptosis with subsequent important effects on bone formation and remodeling. The TGF- $\beta$ /BMP signaling is regulated by various mechanisms at extra-cellular, membrane, cytoplasmic and nuclear levels.

\section{SMADS (Figure 3)}

Smads are signal-transducing molecules of the TGF- $\beta$ super-family. At present, eight mammalian Smad proteins, Smad1 through Smad8, have been isolated and are classified into three subgroups according to their structures and functions: The pathway-restricted Smads (R-Smads), the common mediator Smads (C-Smads) and the inhibitory Smads (I- Smads)..$^{95,96}$

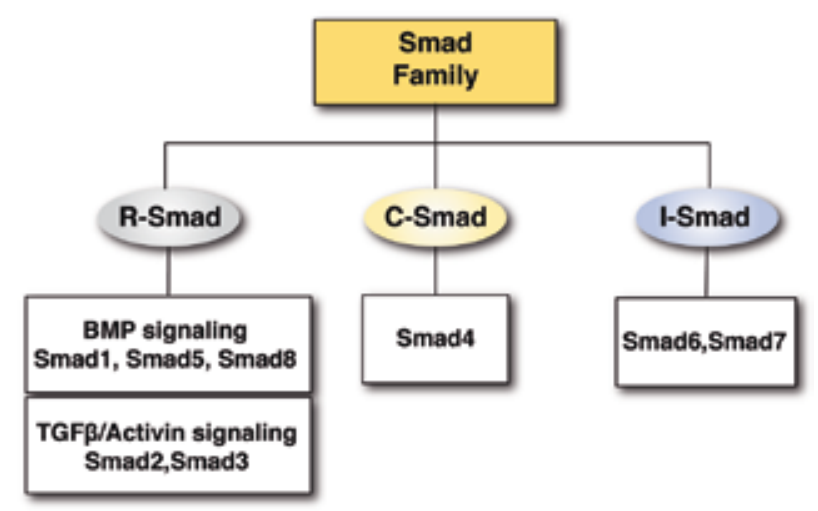

Figure 3. The Smad Family. 


\section{BONE MORPHOGENETIC PROTEINS AND ANTAGONISTS (Figure 4)}

Bone morphogenetic proteins (BMPs) are a group of growth factors known for their ability to induce the formation of bone and cartilage. ${ }^{97}$ Originally, seven such proteins were discovered, six of them (BMP2 through BMP7) belong to the TGF- $\beta$ super-family. Since then, several more BMPs have been discovered (Table 3). BMPs interact with specific receptors on the cell surface, referred to as bone morphogenetic protein receptors (BMPRs). ${ }^{97}$ Signal transduction through BMPRs results in mobilization of members of the Smad family (Smad 1,5,8). A family of secreted BMP antagonists (Noggin, Chordin, Dan and Gremlin) binds BMP ligands and inhibits BMP functions. ${ }^{97,98}$

\section{THE REGULATION OF OSTEOBLASTOGENESIS (Figure 5) AND INTERPRETATION OF PERTINENT CLINICAL PHENOTYPES}

Mesenchymal progenitors can differentiate into a number of cell types, including adipocytes and osteoblasts, myoblasts and chondroblasts. ${ }^{99}$ The exact

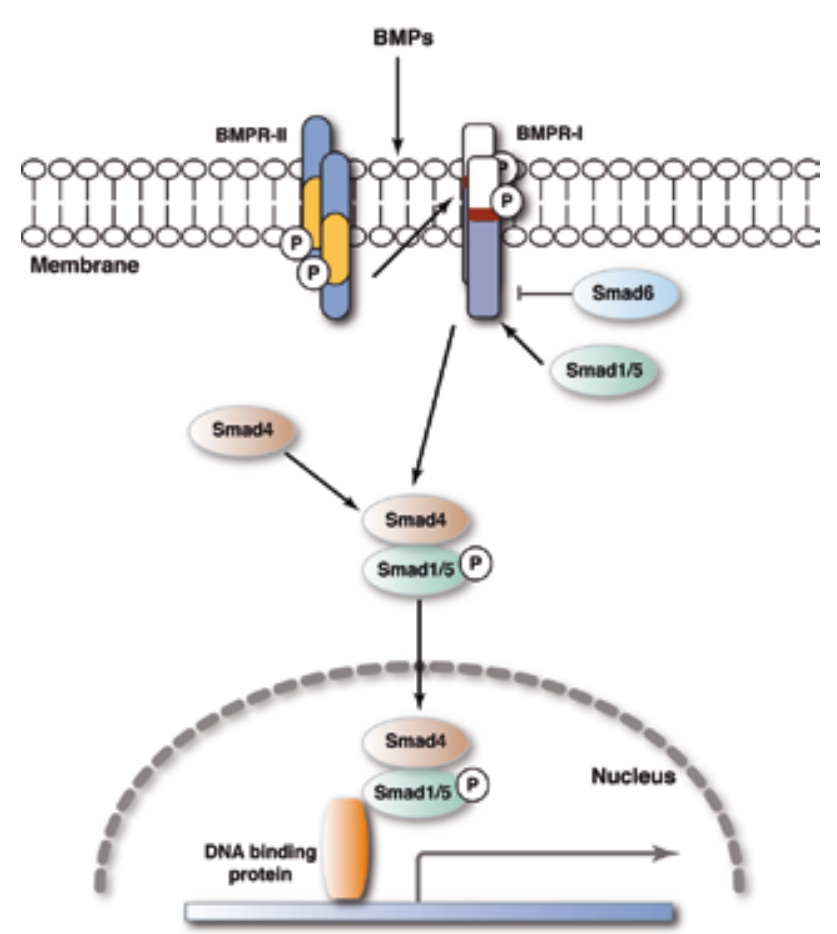

Figure 4. The bone morphogenetic protein signal transduction.
Table 3. The BMP family of proteins.

\begin{tabular}{|c|c|c|}
\hline BMPs & Known Functions & Gene Locus \\
\hline BMP1 & $\begin{array}{l}\text { BMP1 does not belong to the TGF- } \beta \text { family } \\
\text { of proteins. It is a metalloprotease that acts } \\
\text { on procollagen I, II and III. It is involved } \\
\text { in cartilage development. }\end{array}$ & $8 \mathrm{p} 21$ \\
\hline BMP2 & $\begin{array}{l}\text { Acts as a disulfide-linked homodimer and } \\
\text { induces bone and cartilage formation. It is } \\
\text { a candidate as a retinoid mediator. Plays a } \\
\text { key role in osteoblast differentiation. }\end{array}$ & 20p12 \\
\hline BMP3 & Induces bone formation. & $14 \mathrm{p} 22$ \\
\hline BMP4 & $\begin{array}{l}\text { Regulates the formation of teeth, limbs } \\
\text { and bone from mesoderm. It also plays a } \\
\text { role in fracture repair. }\end{array}$ & $14 q 22-q 23$ \\
\hline BMP5 & $\begin{array}{l}\text { Performs functions in cartilage develop- } \\
\text { ment. }\end{array}$ & $6 \mathrm{p} 12.1$ \\
\hline BMP6 & Plays a role in joint integrity in adults. & $6 \mathrm{p} 12.1$ \\
\hline BMP7 & $\begin{array}{l}\text { Plays a key role in osteoblast differen- } \\
\text { tiation. It also induces the production of } \\
\text { SMAD1. Also key in renal development } \\
\text { and repair. }\end{array}$ & $20 \mathrm{q} 13$ \\
\hline BMP8 & $\begin{array}{l}\text { Involved in bone and cartilage develop- } \\
\text { ment. }\end{array}$ & 1p35-p32 \\
\hline BMP8b & Expressed in the hippocampus. & 1p35-p32 \\
\hline BMP10 & $\begin{array}{l}\text { May play a role in the trabeculation of the } \\
\text { embryonic heart. }\end{array}$ & $2 \mathrm{p} 14$ \\
\hline BMP1 & $\begin{array}{l}\text { May play a role in oocyte and follicular } \\
\text { development. }\end{array}$ & Xp11.2 \\
\hline
\end{tabular}

number of factors directing the commitment and maturation of the progenitors in osteoblasts is not yet known. Nonetheless, after the commitment, and probably coordinated by Ror- 2 receptor tyrosine kinase which induces osterix (a downstream to runx2 zinc finger containing transcription factor expressed by osteoblasts and required for endochondral and intramembranous bone formation), ${ }^{100}$ the critical pathway that regulates the reciprocal relationship between adipogenesis and osteoblastogenesis works through canonical Wnt signaling. This signaling inhibits adipogenesis and stimulates osteoblastogenesis of bipotential marrow stromal cells. Activation of Wnt signaling is induced by a number of factors. Recently, the evolving concept of the role of LRP5/6 and its antagonist sclerostin, as a point of mechanotransduction between osteocytes and osteoblast progenitors, focused attention again on the Wnt cascade. The Wnt 


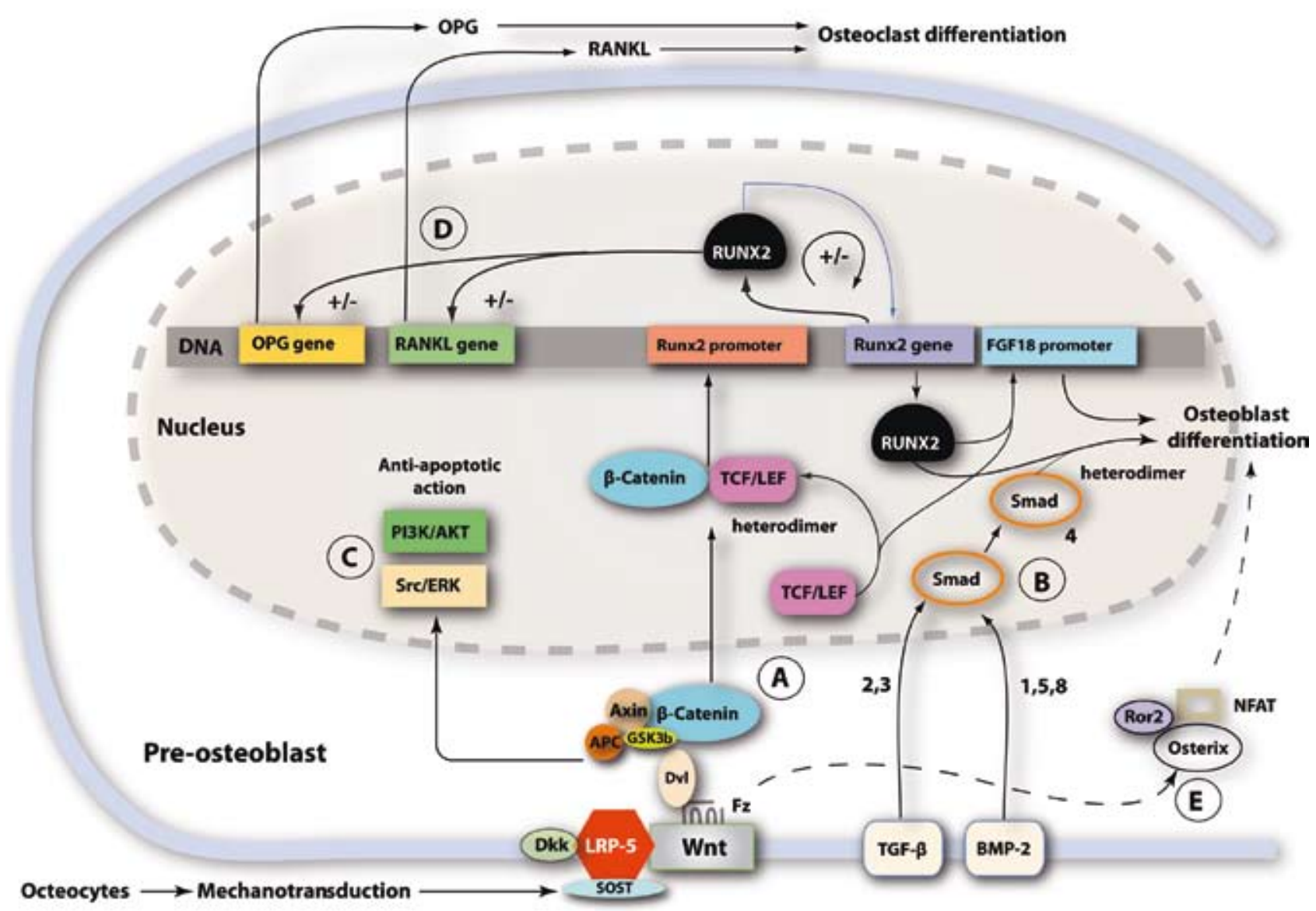

Figure 5. A. The Wnt canonical cascade along with LRP5 regulate the level of $\beta$-catenin in the nucleus. B. The TGF/BMP pathway promotes osteoblastogenesis through interaction with the heterodimer Smad/Runx2. C. The Wnt cascade activates Src/ERK, PI3K/ AKT proteins and promotes anti-apoptotic action. D. The Wnt induced Runx-2 transcription regulates the expression of RANKL and OPG. E. The $\mathrm{Ca}^{2+}$ mediated non-canonical Wnt pathway promote osteoblast differentation through Ror-2/Osterix/NFAT.

pathway, through an elaborate interaction of various components, regulates the expression of certain transcription factors, such as Runx2, Osterix and dlx5, and strongly stimulates osteoblastogenesis. ${ }^{101}$ At the same time, it inhibits the expression of adipogenic transcription factors C/ERB and PPAR $\gamma$ and blocks preadipocyte differentiation. ${ }^{102-105}$ In addition, Wnt signaling up-regulates Runx2 transcription in both committed osteoprogenitor cells and embryonic mesenchymal cells prior to the induction of osteoblast phenotypic genes, promoting the entry of mesenchymal cells into the osteogenic lineage for both endochondral and intramembranous bone formation. ${ }^{106}$ Recent analyses are now providing compelling evidence that thiazolidinediones (TZDs, also known as glitazones), which raise tissue sensitivity to insulin, increase fracture incidence in women taking these medications for the management of diabetes mellitus type 2 . The molecu- lar mechanisms by which bone loss occurs as a result of rosiglitazone (which is a PPAR $\gamma$ agonist) treatment possibly include inhibitory effects on the expression of osteoblast transcription factors Runx 2 and Osterix. This effect is most likely mediated through activation of the adipogenic transcription factor PPAR $\gamma$ resulting in the stimulation of adipogenesis instead of osteoblastogenesis. ${ }^{107}$ Considering the pivotal role of Wnt signaling in stimulating osteoblastogenesis and inhibiting adipogenesis, the interaction between glitazones and Wnt remains to be elucidated. On the other hand, Wnt3a regulates osteoclast differentiation via an indirect mechanism involving, through Runx2, the down-regulation of RANKL expression and induction. ${ }^{108}$ These reciprocal changes in RANKL and OPG expression mediate the effects of Wnt signaling on osteoclast differentiation in vivo. However, two recent papers suggest a strong link between Wnt 
signaling and osteoclast biology. Both studies used transgenic mice, in which the osteoblast lineage was targeted to increase Wnt signaling, resulting in each case to increased osteoprotegerin (OPG) production and decreased osteoclast formation. These mice, with constitutively activated Wnt signaling of osteoblasts, had a severe form of osteopetrosis, but normal osteoblast numbers. These phenotypes thus appeared to be due to failure of osteoclast formation. Although the amounts of OPG produced by the cells from the transgenic mice did not seem to be especially high, the osteoclast phenotype was beyond doubt. ${ }^{109,110}$ In preosteoblasts, activation of Src, ERK and Akt by Wnt3a leads to prevention of apoptosis. In this cell stage, Wnt signaling induces expression of Bcl-2 through a process requiring active ERK. ${ }^{83}$

More interest in the role of the Wnt signaling pathway in bone formation has emerged from the discoveries that gain-of-function mutation in LRP5 leads to a high bone mass phenotype, and loss-of-function mutation leads to the osteoporosis-pseudoglioma syndrome. ${ }^{111,112}$ Nonetheless, it seems that different gain-of-function mutations in LRP5 result in high bone mass through different mechanisms. The high bone mass phenotype in human subjects with a G171V mutation in LRP5 is the result of increased osteoblast activity, with normal resorption parameters. On the other hand, patients with autosomal dominant osteopetrosis type I (ADOI) due to T253I mutation in LRP5 manifest an osteopetrotic phenotype, with lower numbers of osteoclasts in vivo, ${ }^{113-115}$ but show no increase in bone formation markers. In addition, multiple myeloma cells express high levels of Dkk1, and it is well known that Dkk1 expression underlies the well-known inhibition of bone formation in osteolytic lesions of myeloma. ${ }^{116}$ Treatment with a neutralizing Dkk1 antibody markedly increased bone mass and osteoblast number. ${ }^{117}$ Moreover, osteoclast number and tumor burden were both diminished, suggesting that Dkk1 has a central role in both the osteolytic phase of multiple myeloma and the uncoupling of bone destruction from the usual osteoblastic response. Given the complexity of the Wnt system, with its receptor complex of inhibitory and stimulatory components, its decoy receptors, the multi-protein inhibitory complex acting on GSK3b and the necessary phosphorylation steps, it should perhaps be expected that subtly different mechanisms would emerge for the control of activation.

\section{CONCLUSIONS}

It is now widely accepted that the antiresorptive treatment of osteoporosis is not adequate, since it only partially reduces the risk of fractures and does not correlate with a remarkable increase of bone mass. Therefore, the research for anabolic agents which target osteoblast function is beginning to gain a new momentum. The Wnt pathway was discovered nearly 20 years ago and today is mentioned in more than 5000 articles listed on pubmed, over half of which have been published in the last 3 years. This intense interest in bone modeling research is mostly driven by the fact that Wnt has proved to be a major mediator of osteoblastogenesis and osteoclastogenesis both in vitro and in vivo. Our growing knowledge of the complexities of the Wnt protein and other components of the Wnt pathway as well as the multiple interactions with other protein systems such as BMPs and TGF provides an attractive field for research and therapeutic intervention. Some of the challenges that exist in targeting this pathway for therapeutic intervention are that some of the well-validated targets like LRP-5, DKK-1 and sclerostin are not members of traditional drug classes of proteins such as enzymes, hormone receptors and ion channels. Moreover, many of these potential targets, for instance LRP-5 and GSK3b, have broad tissue distribution and pharmacologic modulation at these sites may therefore have unwanted side effects like cancer. ${ }^{118}$ Treatment of mice with lithium cloride, which inhibits GSK3b, increases bone formation and bone mass in osteopenic animals by suppressing osteoblast apoptosis and adipogenesis while enhancing osteogenesis. ${ }^{119}$ Lithium has been used for decades to treat bipolar disorder, and in patients treated with this drug a reduced relative risk of fracture was observed. ${ }^{120}$ GSK3b inhibitors have also been developed for a variety of non-skeletal indications, including type 2 diabetes and Alzheimer's disease, ${ }^{121}$ but, as yet, none of these compounds have entered clinical development for osteoporosis. Therapeutic antibodies that neutralize the secreted Wnt antagonist's sclerostin and DKK-1 are currently in late preclinical/early clinical development. ${ }^{122,123}$ In addition to being a potential therapeutic agent for 
osteoporosis, an antagonist of DKK-1 has application for the treatment of other skeletal diseases like rheumatoid arthritis and osteolytic lesions of multiple myeloma. $^{124-126}$

However, as new molecules emerge from ongoing drug discovery efforts that target aspects of the Wnt signaling pathway, attention to tumor potential and other forms of toxicity will be of paramount importance. Evidence that dysregulation of Wnt signaling is a contributing factor in a number of human diseases continues to accumulate. Corroborating evidence showed that a mutation of APC causes familial adenomatous polyposis, a condition that inevitably leads to colorectal cancer. ${ }^{127}$ Recently, a missense mutation in LRP6 was identified in a family with autosomal dominant early coronary artery disease and osteoporosis. ${ }^{128}$ Evidence also exists that decreased nuclear $\beta$-catenin expression may be involved in choriocarcinoma carcinogenesis. ${ }^{129}$ There is no doubt that the Wnt targeted research will expand rapidly in the next few years and pertinent results will most likely define the intervention limits.

\section{REFERENCES}

1. Pandur P, Maurus D, Kuhl M, 2002 Increasingly complex: new players enter the Wnt signaling network. BioEssays 24: 881-884.

2. Logan CY, Nusse R, 2004 The Wnt signaling pathway in development and disease. Annu Rev Cell Dev Biol 20: 781-810.

3. Wodarz A, Nusse R, 1998 Mechanisms of Wnt signal transduction. Annu Rev Cell Dev Biol 14: 59-88.

4. Tamai K, Semenov M, Kato Y, et al, 2000 LDL-receptor-related proteins in Wnt signal transduction. Nature 407: 530-535.

5. He X, Semenov M, Tamai K, Zeng X, 2004 Development (Camb) 131: 1663-1677.

6. Ruel L, Stambolic V, Ali A, Manoukian AS, Woodgett JR, 1999 Regulation of the protein kinase activity of Shaggy (Zeste-white3) by components of the wingless pathway in Drosophila cells and embryos. J Biol Chem 274: 21790-21796.

7. Liu C, Li Y, Semenov M, et al, 2002 Control of $\beta$-catenin phosphorylation/degradation by a dual-kinase mechanism. Cell 108: 837-847.

8. Veeman MT, Axelrod JD, Moon RT, 2003 A second canon. Functions and mechanisms of $\beta$-catenin-independent Wnt signaling. Dev Cell 5: 367-377.

9. Willert K, Brown JD, Danenberg E, et al, 2003 Wnt proteins are lipid-modified and can act as stem cell growth factors. Nature 423: 448-452.

10. Nusse R, 2003 Wnts and Hedgehogs: Lipid-modified proteins and similarities in signaling mechanisms at the cell surface. Development 130: 5297-5305.

11. Johnson ML, Harnish K, Nusse R, Van Hul W, 2004 LRP5 and Wnt signaling: A union made for bone. J Bone Mineral 19: 1749-1757.

12. Galli LM, Barnes TL, Secrest SS, Kadowaki T, Burrus LW, 2007 Porcupine-mediated lipid-modification regulates the activity and distribution of Wnt proteins in the chick neural tube. Development 134: 3339-3348

13. Mason JO, Kitajewski J, Varmus HE, 1992 Mutational analysis of mouse Wnt-1 identifies two temperature-sensitive alleles and attributes of Wnt-1 protein essential for transformation of a mammary cell line. Mol Biol Cell 3: 521-533.

14. Niemann S, Zhao C, Pascu F, et al, 2004 Homozygous Wnt-3 mutation causes tetra-amelia in a large consanguineous family. Am J Hum Genet 74: 558-563.

15. Biason-Lauber A, Konrad D, Navratil F, Schoenle EJ, 2004 Wnt-4 mutation associated with Mullerian-duct regression and virilization in a 46,XX woman. $\mathrm{N}$ Engl $\mathrm{J}$ Med 351: 792-798.

16. Kanazawa A, Tsukada S, Sekine A, et al, 2004 Association of the gene encoding wingless-type mammary tumor virus integration-site family member $5 \mathrm{~B}(\mathrm{Wnt}-5 \mathrm{~B})$ with type 2 diabetes. Am J Hum Genet 75: 832-843.

17. Christodoulides C, Scarda A, Granzotto M, et al, 2006 Wnt-10B mutations in human obesity. Diabetologia 49: 678-684.

18. Strickland DK, Gonias SL, Argraves WS, 2002 Diverse roles for the LDL receptor family. Trends Endocrinol Metab 13: 66-74.

19. Wehrli M, Dougan ST, Caldwell K, O'Keefe L, 2000 Arrow encodes an LDL-receptor-related protein essential for wingless signaling. Nature 407: 527-530.

20. Brown SD, Twells RC, Hey PJ, et al, 1998 Isolation and characterization of LRP6, a novel member of the low density lipoprotein receptor gene family. Biochem Biophys Res Commun 248: 879-888.

21. Schweizer L, Varmus H, 2003 Wnt/Wingless signaling through $\beta$-catenin requires the function of both LRP/Arrow and frizzled classes of receptors. BMC Cell Biol 4: 4.

22. Bhanot P, Brink M, Harryman Samos C, et al, 1996 A new member of the frizzled family from Drosophila functions as a Wingless receptor. Nature 382: 225-230.

23. Moon RT, Brown JD, Yang-Snyder JA, Miller JR, 1997 Structurally related receptors and antagonists compete for secreted Wnt ligands. Cell 88: 725-728.

24. Hsieh JC, Rattner A, Smallwood PM, Nathans J, 1999 Biochemical characterization of Wnt-frizzled interactions using a soluble, biologically active vertebrate Wnt protein. Proc Nat Acad Sci USA 96: 3546-3551.

25. Dann CE, Hsieh JC, Rattner A, et al, 2001 Insights into Wnt binding and signaling from the structures of two Frizzled cysteine-rich domains. Nature 412: 86-90. 
26. Sheldahl LC, Park M, Malbon CC, Moon RT, 1999 Protein kinase $\mathrm{C}$ is differentially stimulated by Wnt and Frizzled homologs in a G-protein-dependent manner. Curr Biol 9: 695-698.

27. Glinka AW, Wu W, Delius H, et al, 1998 Dickkopf-1 is a member of a new family of secreted proteins and functions in head induction. Nature 391: 357-362.

28. Bafico P, Liu G, Yaniv A, Gazit A, Aaronson AA, 2001 Novel mechanism of Wnt signaling inhibition mediated by Dickkopf-1 interaction with LRP6/Arrow. Nat Cell Biol 3: 683- 686.

29. Mao B, Wu W, Li Y, et al, 2001 LDL-receptor-related protein 6 is a receptor for Dickkopf proteins. Nature 411: 321-325.

30. Mao B, Wu W, Davidson G, et al, 2002 Kremen proteins are Dickkopf receptors that regulate $\mathrm{Wnt} / \beta$-catenin signaling. Nature 417: 664-667.

31. Mao B, Niehrs C, 2003 Kremen2 modulates Dickkopf-2 activity during Wnt/LRP6 signaling. Gene 302: 179-183.

32. Li X, Liu P, Maye P, et al, 2005 Dkk2 has a role in terminal osteoblast differentiation and mineralized matrix formation. Nat Genet 37: 945-952.

33. Balemans W, Ebeling M, Patel N, et al, 2001 Increased bone density in sclerosteosis is due to the deficiency of a novel secreted protein (SOST). Hum Mol Genet 10: 537-543.

34. Brunkow ME, Gardner JC, Van Ness J, et al, 2001 Bone dysplasia sclerosteosis results from loss of the SOST gene product, a novel cysteine knot-containing protein. Am J Hum Genet 68: 577-589.

35. Winkler DG, Sutherland MK, Geoghegan JC, et al, 2003 Osteocyte control of bone formation via sclerostin, a novel BMP antagonist. EMBO J 22: 6267-6276.

36. Avsian-Kretchmer O, Hsueh AJ, 2004 Comparative genomics analysis of the eight-membered-ring cystineknot-containing bone morphogenetic protein (BMP) antagonists. Mol Endocrinol 18: 1-12.

37. van Bezooijen RL, Roelen BA, Visser A, et al, 2004 Sclerostin is an osteocyte-expressed negative regulator of bone formation, but not a classical BMP antagonist $\mathbf{J}$ Exp Med 199: 805-814.

38. van Bezooijen RL, Svensson JP, Eefting D, et al, 2007 Wnt but not BMP signaling is involved in the inhibitory action of sclerostin on BMP-stimulated bone formation. J Bone Miner Res 22: 19-28.

39. Ellies DL, Viviano B, McCarthy J, et al, 2006 Bone density ligand, Sclerostin, directly interacts with LRP5 but not LRP5G171V to modulate Wnt activity. J Bone Miner Res 21: 1738-1749.

40. Lowik CW, van Bezooijen RL, 2006 Wnt signaling is involved in the inhibitory action of sclerostin on BMPstimulated bone formation. J Musculoskelet Neuronal Interact 6: 357 .

41. Li X, Zhang Y, Kang H, et al, 2005 Sclerostin binds to LRP5/6 and antagonizes canonical Wnt signaling. J Biol Chem 280: 19883-19887.
42. Itasaki N, Jones CM, Mercurio S, et al, 2003 Wise, a context-dependent activator and inhibitor of Wnt signaling. Development 130: 4295-4305.

43. Finch PW, He X, Kelley MJ, et al, 1997 Purification and molecular cloning of a secreted, Frizzled-related antagonist of Wnt action. Proc Natl Acad Sci USA 94: 6770-6775.

44. Hausler KD, Horwood NJ, Uren A, et al, 2001 Secreted Frizzled-related protein (sFRP-1) binds to RANKL to inhibit osteoclast formation. J Bone Miner Res 16: S153.

45. Lee JL, Lin CT, Chueh LL, Chang CJ, 2004 Autocrine/ Paracrine Secreted Frizzled-related Protein 2 Induces Cellular Resistance to Apoptosis: a possible mechanism of mammary tumorigenesis. J Biol Chem 279: 1460214609.

46. Abu-Jawdeh G, Comella N, Tomita Y, 1999 Differential expression of frpHE: a novel human stromal protein of the secreted frizzled gene family, during the endometrial cycle and malignancy. Lab Invest 79: 439-447.

47. Hsieh JC, Kodjabachian L, Rebbert ML, 1999 A new secreted protein that binds to Wnt proteins and inhibits their activities. Nature 398: 431-436.

48. Axelrod JD, Miller JR, Shulman JM, et al, 1998 Differential recruitment of dishevelled provides signaling specificity in the planar cell polarity and signaling pathways. Genes Dev 12: 2610-2622.

49. Klingensmith J, Nusse R, Perrimon N, 1994 The drosophila segment polarity gene dishevelled encodes a novel protein required for response to the wingless signal. Genes Dev 8: 118-130.

50. Sussman DJ, Klingensmith J, Salinas P, et al, 1994 Isolation and characterization of a mouse homolog of the drosophila segment polarity gene dishevelled. Dev Biol 166: 73-86.

51. Theisen H, Purcell J, Bennett M, et al, 1994 Dishevelled is required during wingless signaling to establish both cell polarity and cell identity. Development 120: 347-360.

52. Krasnow RE, Wong LL, Adler PN, 1995 Dishevelled is a component of the frizzled signaling pathway in Drosophila. Development 121: 4095-102.

53. Penton A, Wodarz A, Nusse R, 2002 A mutational analysis of dishevelled in drosophila defines novel domains in the dishevelled protein as well as novel suppressing alleles of axin. Genetics 161: 747-762.

54. Itoh K, Brott BK, Bae GU, Ratcliffe MJ, Sokol SY, 2005 Nuclear localization is required for dishevelled function in Wnt/ $\beta$-catenin signaling. J Biol 4: 3.

55. Smalley MJ, Sara E, Paterson H, et al, 1999 Interaction of axin and Dvl-2 proteins regulates Dvl-2-stimulated TCF-dependent transcription. The EMBO Journal 18: 2823-2835.

56. Krishnan V, Bryant HU, MacDougald OA, 2006 Regulation of bone mass by Wnt signaling. J Clin Invest 116 : 1202-1209.

57. Mao J, Wang J, Liu B, et al, 2001 Low-Density Lipoprotein 
Receptor-Related Protein-5 binds to axin and regulates the canonical Wnt signaling pathway. Molecular Cell 7: 801-809.

58. Ikeda S, Kishida S, Yamamoto H, et al, 1998 Axin, a negative regulator of the Wnt signaling pathway, forms a complex with GSK-3b and $\beta$-catenin and promotes GSK-3b-dependent phosphorylation of $\beta$-catenin. EMBO J 17: 1371-1384.

59. Behrens J, Jerchow BA, Wurtele M, et al, 1998 Functional interaction of an axin homolog, conductin, with $\beta$-catenin, APC, and GSK-3b. Science 280: 596-599.

60. Lustig B, Jerchow B, Sachs M, et al, 2002 Negative feedback loop of Wnt signaling through upregulation of conductin/axin2 in colorectal and liver tumors. Mol Cell Biol 22: 1184-1193.

61. Jho EH, Zhang T, Domon C, Joo CK, Freund JN, Costantini F, $2002 \mathrm{Wnt} / \beta$-catenin/Tcf signaling induces the transcription of Axin2, a negative regulator of the signaling pathway. Mol Cell Biol 22: 1172-1183.

62. Chia IV, Constantini F, 2005 Mouse axin and axin2/conductin proteins are functionally equivalent in vivo. Mol Cell Biol 25: 4371-4376.

63. Lammi L, Arte S, Somer M, et al, 2004 Mutations in AXIN2 cause familial tooth agenesis and predispose to colorectal cancer. Am J Hum Genet 74: 1043-1050.

64. NXthke IS, 2004 The adenomatus poliposis coli protein: The Achilles heel of the gut epithelium. Annual Review of Cell and Developmental Biology 20: 337-366.

65. Ahmed Y, Nouri A, Wieschaus E, 2002 Drosophila Apc1 and Apc2 regulate Wingless transduction throughout development. Development 129: 1751-1762.

66. Dajani R, Fraser E, Roe SM, et al, 2003 Structural basis for recruitment of glycogen synthase kinase 3beta to the axin-APC scaffold complex. EMBO J 22: 494-501.

67. Li L, Yuan H, Weaver CD, et al, 1999 Axin and Frat1 interact with Dvl and GSK, bridging Dvl to GSK in Wnt-mediated regulation of LEF-1. EMBO J 18: 42334240.

68. Bax B, Carter PS, Lewis C, et al, 2001 The structure of phosphorylated GSK-3beta complexed with a peptide, FRATtide, that inhibits $\beta$-catenin phosphorylation. Structure 9: 1143-1152.

69. Cross DA, Alessi DR, Cohen P, Andjelkovich M, Hemmings BA, 1995 Inhibition of glycogen synthase kinase-3 by insulin mediated by protein kinase B. Nature 378: 785-789.

70. Dajani R, Fraser E, Roe SM, et al, 2001 Crystal structure of glycogen synthase kinase $3 \beta$ : structural basis for phosphate-primed substrate specificity and autoinhibition. Cell 105: 721-732.

71. Frame S, Cohen P, Biondi RM, 2001 A common phosphate binding site explains the unique substrate specificity of GSK-3 and its inactivation by phosphorylation. Mol Cell 7: 1321-1327.

72. Farr GH, Ferkey DM, Yost C, et al, 2000 Interaction among GSK-3, GBP, axin, and APC in Xenopus axis specification. J Cell Biol 148: 691-702.

73. Ding VW, Chen RH, McCormick F, 2000 Differential regulation of glycogen synthase kinase 3 beta by insulin and Wnt signaling. J Biol Chem 275: 32475-32481.

74. Salic A, Lee E, Mayer L, Kirschner MW, 2000 Control of $\beta$-catenin stability: reconstitution of the cytoplasmic steps of the wnt pathway in Xenopus egg extracts. Mol Cell 5: 523-532.

75. Liu C, Li Y, Semenov M, et al, 2002 Control of $\beta$-catenin phosphorylation and degradation by a Dual-Kinase Mechanism. Cell 108: 837-847.

76. Gumbiner BM, 1995 Signal transduction by $\beta$-catenin. Curr Opin Cell Biol 7: 634-640.

77. Urbach $S$, Wingender $E$, Involvement of $\beta$-catenin in signal transduction and activation of $\mathrm{TCF} / \mathrm{LEF}$ regulated target genes. Biobase Biological Databases GmbH.

78. Fujita T, Azuma Y, Fukuyama R, et al, 2004 Runx-2 induces osteoblast and chondrocyte differentiation and enhances their migration by coupling with PI3K-Akt signaling. J Cell Biol 166: 85-95.

79. Almeida M, Li Han, Bellido T, Manolagas SC, Kousteni S, $2005 \mathrm{Wnt}$ proteins prevent apoptosis of both uncommitted osteoblast progenitors and differentiated osteoblasts by catenin-dependent and -independent signaling cascades involving Src/ERK and phosphatidylinositol 3-Kinase/Akt. J Biol Chem 280: 41342-41351.

80. Bienz M, 1998 TCF: transcriptional activator or repressor? Curr Opin Cell Biol 10: 366-372.

81. Cavallo RA, Cox RT, Moline MM, et al, 1998 Drosophila Tcf and Groucho interact to repress Wingless signaling activity. Nature 395: 604-608.

82. Komori T, Yagi H, Nomura S, et al, 1997 Targeted disruption of Cbfa-1 results in a complete lack of bone formation owing to maturational arrest of osteoblasts. Cell 89: 755-764.

83. Banerjee C, McCabe LR, Choi J-Y, et al, 1997 Runt homology domain proteins in osteoblast differentiation: AML-3/CBFA-1 is a major component of a bone specific complex. J Cell Biochem 66: 1-8.

84. Ducy P, Zhang R, Geoffroy V, Ridall AL, Karsenty G, 1997 Osf2/Cbfa-1: a transcriptional activator of osteoblast differentiation. Cell 89: 747-754.

85. Reinhold MI, Naski MC, 2006 Direct interactions of Runx-2 and canonical Wnt signaling induce FGF-18. J Biol Chem. 11 [Epub ahead of print]

86. Gordon MD, Nusse R, 2006 Wnt Signaling: Multiple Pathways, Multiple Receptors, and Multiple Transcription Factors. J Biol Chem 281: 22429-22433.

87. Cavallo RA, Cox RT, Moline MM, et al, 1998 Drosophila Tcf and Groucho interact to repress Wingless signaling activity. Nature 395: 604-608.

88. Chen G, Fernandez J, Mische S, Courey AJ, 1999 A functional interaction between the histone deacetylase Rpd3 and the corepressor Groucho in Drosophila development. Genes Dev 13: 2218-2230.

89. Hecht A, Vleminckx K, Stemmler MP, van Roy F, 2000 
The p300/CBP acetyltransferases function as transcriptional coactivators of $\beta$-catenin in vertebrates. EMBO J 19: $1839-1850$.

90. Takemaru KI, Moon RT, 2000 The transcriptional coactivator CBP interacts with $\beta$-catenin to activate gene expression. J Cell Biol 149: 249-254.

91. Lévy L, Wei Y, Labalette C, et al, 2004 Acetylation of $\beta$-catenin by $\mathrm{p} 300$ regulates $\beta$-catenin-Tcf- 4 interaction. Mol Cell Biol 24: 3404-3414.

92. Strutt D, 2003 Frizzled signaling and cell polarisation in Drosophila and vertebrates. Development 130: 45014513.

93. Penton A, Wodarz A, Nusse R, 2002 A mutational analysis of dishevelled in Drosophila defines novel domains in the dishevelled protein as well as novel suppressing alleles of axin. Genetics 161: 747-762.

94. Axelrod JD, McNeill H, 2002 Coupling planar cell polarity signaling to morphogenesis. Scientific World J 2: 434-454.

95. Miyazono K, 2000 TGF- $\beta$ signaling by Smad proteins. Cytokine Growth Factor Rev 11: 15-22.

96. Massague J, 1998 TGF- $\beta$ signal transduction. Annu Rev Biochem 67: 753-791.

97. Chen D, Zhao M, Mundy GR, 2004 Bone Morphogenetic Proteins. Growth Factors 22: 233-241.

98. Groppe J, Greenwald J, Wiater E, et al, 2002 Structural basis of BMP signaling inhibition by the cystine knot protein Noggin. Nature 420: 636-642.

99. Nuttall ME, Gimble JM, 2004 Controlling the balance between osteoblastogenesis and adipogenesis and the consequent therapeutic implications. Curr Opin Pharmacol 4: 290-294.

100. Cao Y, Zhou Z, de Crombrugghe B, et al, 2005 Osterix, a transcription factor for osteoblast differentiation, mediates antitumor activity in murine osteosarcoma. Cancer Res 65: 1124-1128.

101. Bennett CN, Longo KA, Wright WS, 2005 Regulation of osteoblastogenesis and bone mass by Wnt-10b. Pnas 102: 3324-3329.

102. Ross SE, Hemati N, Longo KA, et al, 2000 Inhibition of adipogenesis by Wnt signaling. Science 289: 950-953.

103. Bennett CN, Ross SE, Longo KA, 2002 Regulation of Wnt signaling during adipogenesis. J Biol Chem 277: 30998-31004.

104. Kennell JA, O’Leary EE, Gummow BM, Hammer GD, MacDougald OA, 2003 T-cell factor 4N (TCF-4N), a novel isoform of mouse TCF-4, synergizes with $\beta$-catenin to coactivate $\mathrm{C} / \mathrm{EBPalpha}$ and steroidogenic factor 1 transcription factors. Mol Cell Biol 23: 5366-5375.

105. Moldes M, Zuo Y, Morrison RF, et al, 2003 Peroxisome-proliferator-activated receptor gamma suppresses $\mathrm{Wnt} / \beta$-catenin signaling during adipogenesis. J Bio Chem 376: 607-613.

106. Gaur T, Lengner CJ, Hovhannisyan H, et al, 2005 Canonical Wnt signaling promotes osteogenesis by directly stimulating Runx-2 gene expression. J Bio Chem 280:
33132-33140.

107. Andrews NA, 2007 All That Glitazones Is Not Gold: Popular medications used to treat type 2 diabetes appear to increase fracture risk. BoneKEy-Osteovision. 4: 94-98.

108. Spencer GJ, Utting JC, Etheridge SL, Arnett TR, Genever PG 2005 Wnt signaling in osteoblasts regulates expression of the receptor activator of $\mathrm{NF} x \mathrm{~B}$ ligand and inhibits osteoclastogenesis in vitro. J Cell Sci 119: 1283-1296.

109. Glass DA 2nd, Bialek P, Ahn JD, et al, 2005 Canonical Wnt signaling in differentiated osteoblasts controls osteoclast formation. Dev Cell(5):751-64

110. Thirunavukkarasu K, Halladay DL, Miles RR, et al, 2000 The osteoblast-specific transcription factor Cbfa1 contributes to the expression of osteoprotegerin, a potent inhibitor of osteoclast differentiation and function. J Biol Chem. 275: 25163-25172.

111. Bollerslev J, Marks SC Jr, Pockwinse S, et al, 1993 Ultrastructural investigations of bone resorptive cells in two types of autosomal dominant osteopetrosis. Bone 14: 865-869.

112. Bollerslev J, Steiniche T, Melsen F, Mosekilde L, 1989 Structural and histomorphometric studies of iliac crest trabecular and cortical bone in autosomal dominant osteopetrosis: a study of two radiological types. Bone 10: $19-24$.

113. Henrikson K, Gram J, Joeghe-Anderson P, et al, 2005 Osteoclasts from patients with autosomal dominant osteopetrosis type 1 caused by a T253I mutation in lowdensity lipoprotein receptor -related protein 5 are normal in vitro, but have decreased resorption capacity in vivo. Am J Path. 167 (in press)

114. Bollerslev J, Ueland T, Grodum E, et al, 1998 Biochemical markers of bone metabolism in benign human osteopetrosis: a study of two types at baseline and during stimulation with triiodothyronine. Eur J Endocrinol 139: 29-35.

115. Moon RT, Kohn AD, De Ferrari GV, Kaykas A, 2004 WNT and $\beta$-catenin signaling: diseases and therapies. Nat Rev Genet 5: 691-701.

116. Tian E, Zhan F, Walker R, et al, 2003 The role of the Wnt-signaling antagonist DKK1 in the development of osteolytic lesions in multiple myeloma. N Engl J Med 349: 2483-2494.

117. Yaccoby S, Ling W, Zhan F, et al, 2007 Antibody-based inhibition of DKK1 suppresses tumor-induced bone resorption and multiple myeloma growth in vivo. Blood 109: 2106-2111.

118. Moon RT, Kohn AD, De Ferrari GV, Kaykas A, 2004 WNT and beta-catenin signalling: diseases and therapies. Nat Rev Genet 5: 691-701.

119. Clement-Lacroix P, Ai M, Morvan F, et al, 2005 Lrp5-independent activation of Wnt signaling by lithium chloride increases bone formation and bone mass in mice. Proc Natl Acad Sci U S A 29:102

120. Vestergaard P, Rejnmark L, Mosekilde L, 2005 Reduced 
relative risk of fractures among users of lithium. Calcif Tissue Int 77: 1-8.

121. Meijer L, Flajolet M, Greengard P, 2004 Pharmacological inhibitors of glycogen synthase kinase 3 . Trends Pharmacol Sci. 25: 471-480.

122. Grisanti M, Niu QT, Fan W, et al, 2006 Dkk-1 inhibition increases bone mineral density in rodents. J Bone Miner Res 21: Suppl 1: S25.

123. Ominsky M, Stouch B, Doellgast G, et al, 2006 Administration of sclerostin monoclonal antibodies to female cynomolgus monkeys results in increased bone formation, bone mineral density and bone strength. J Bone Miner Res 21: Suppl 1: 44.

124. Diarra D, Stolina M, Polzer K, et al, 2007 Dickkopf-1 is a master regulator of joint remodeling. Nat Med 13: 156-163.
125. Tian E, Zhan F, Walker R, et al, 2003 The role of the Wnt-signaling antagonist DKK1 in the development of osteolytic lesions in multiple myeloma. N Eng J Med 349: 2483-2494.

126 Yaccoby S, Ling W, Zhan F, Walker R, Barlogie B, Shaughnessy JD Jr, 2007 Antibody-based inhibition of DKK1 suppresses tumor-induced bone resorption and multiple myeloma growth in vivo. Blood 109: 2106-2111.

127. Bodmer WF, 2006 Cancer genetics: colorectal cancer as a model. J Hum Genet 51: 391-396.

128. Mani A, Radhakrishnan J, Wang H, et al, 2007 LRP6 mutation in a family with early coronary disease and metabolic risk factor. Science 315: 1278-1282.

129. Wong SCC, Chan ATC, Chan JKC, Lo YMD, 2006 Nuclear $\beta$-catenin and $\mathrm{Ki}-67$ expression in choriocarcinoma and its pre-malignant form. J Clin Pathol 59: 387-392. 